\title{
Urban expansion, the politics of land, and occupation as infrastructure in Kinshasa
}

\author{
Filip De Boeck \\ Institute for Anthropological Research in Africa, University of Leuven, Belgium
}

\section{A R T I C L E I N F O}

\section{Keywords:}

Land use policy

Land chiefs

Democratic Republic of Congo

Kinshasa

Urban expansion

\begin{abstract}
A B S T R A C T
This article demonstrates how the future of Kinshasa, the capital of the Democratic Republic of Congo is partly to be found in its past. It looks at the complex and often ambivalent role many autochthonous land chiefs continue to play in the processes of urban expansion currently taking place in Kinshasa.
\end{abstract}

\section{Introduction}

If current patterns of urban expansion in Africa are marked by the development of 'oceans of poverty containing islands of wealth', as stated in the 2010 UN Habitat Report on The State of African Cities (UN Habitat, 2010), then it is becoming increasingly clear that these 'islands', often materializing in the form of platform infrastructures such as gated communities and satellite cities, are under constant threat of being sucked straight back again into the unstable sludge of the urban swamp from which they try to distance themselves.

In Kinshasa (formerly Léopoldville), the megalopolis that sits along the mighty Congo river and is the capital of the Democratic Republic of Congo, the genealogy of contemporary urban space is shaped not only by forces of colonialist modernity, and more recently the workings of neo-liberalism, but also, and to a considerable extent, through continuations and adaptations of older, longstanding, less discernible though very present social and cultural infrastructures, habituses, moral matrixes and ideas about what constitutes social well-being, for example, or power, wealth, property and collective identity. Centered around specific politics of land access and notions of value, attachment and belonging in relation to land (Lingala: mabele), as is often the case in other African contexts as well (cf. Lund, 2008; Shipton, 2009) these are histories of specific modes and forms of mobility and of particular logics of seizure, occupation and distribution, originating from precisely the kind of social and cultural worlds that (post-)colonial cityplanners and investors have tried to ban from the urban surface. Yet, it is this longue durée perspective that continues to impact strongly upon the city, drives it forward and enables it to grow and expand. Illustrating the need to theorize the urban present beyond the idea of modernity or the 'new' (Robinson, 2013), this contribution argues that, in order to understand current urban growth patterns and 'the city yet to come' (Simone, 2004), it is necessary to research to which extent these pasts continue to haunt and enchant the urban present and to impact upon the shape of its possible futures. Without such knowledge of the historical residues of plural legal land systems it becomes impossible to design an effective urban land use policy.

In the remainder of this text I will demonstrate how Kinshasa's future is partly to be found in its past, by looking at the complex and often ambivalent role many autochthonous land chiefs continue to play in processes of urban expansion. I also provide a brief history of local Humbu and Teke chiefs under colonial rule, and discuss the impact of postcolonial land reforms by means of a more detailed case study that focuses on an ongoing land dispute along Kinshasa's Malebo Pool. I argue that chiefs, even while their importance has greatly diminished in many ways, remain crucial figures who enable access to land and thereby allow for urban expansion. But their continued involvement in land matters also operates as a very efficacious form of urban sabotage that deeply disturbs, perverts and deregulates the city's functioning on an institutional level. The ways in which these land chiefs continue to shape access to land by infusing pre-urban moralities and ideologies into post-colonial urban settings greatly complexifies standard understandings of urban/rural oppositions, thereby illustrating the necessity to rethink such simple dichotomies.

\section{Autochthonous notions of 'commons' and contemporary urban growth}

April 2013. On the rooftop of a decrepit bar somewhere in one of

E-mail address: Filip.Deboeck@kuleuven.be.

${ }^{1}$ The ethnography presented here builds on several months of fieldwork that I carried out in Kinshasa between 2008 and 2015. 
Kinshasa's many cités a local Yaka band is rehearsing. Kas Kasongo, the orchestra's young and charismatic lead singer briefly gained national recognition in 2011 with his song Sisa Bidimbu in praise of Kabila's 'revolution of modernity' and the new Kinshasa that it promised (see De Boeck and Baloji, 2016: 2011). ${ }^{2}$ Today, Kas seems to have forgotten that he once showered Kabila with praise for his urban renewal program. The orchestra starts to play an energetic tune that is based on the rhythmical pattern of a standard Yaka folk song, and then Kas's incantatory voice breaks into the rhythm. Kinshasa ebeba, he sings, 'the city has rotted', 'And you who live in the village, don't pity yourselves / The Kinshasa that we have migrated to has become a village full of suffering, problems and contradictions / Ah, poor me, Kinshasa has completely deteriorated / And the way to Europe is also closed.'

The next song at the rehearsal is called Meni $N$-Yaka ('I am a muYaka') ${ }^{3}$ in which Kas Kasongo relates how 'the baYaka founded Kinshasa':

It is me, the muYaka who created Kinshasa.

Kinshasa, the city that feeds young and old.

First I settled in Angola.

Then I also settled in Lunda. ${ }^{4}$

When I noticed that our village had become too crowded I left.

Now I am close to the Beach [Kinshasa's port].

I built a canoe to cross the river.

I came to Kinshasa on foot, I did not have an airplane.

I came to Kinshasa on foot, I did not have a truck.

I am the son of the lion and the leopard. ${ }^{5}$

When I arrived in Kinshasa there was nobody.

The muTeke lived on the other side of the Congo river.

The muTeke came from the other side to sell his fish.

In the old days, the White Man asked me: 'What is the name of this place?'

I answered: 'It is Kinshasa.'

Kinshasa, the city that feeds young and old.

Me, muYaka, when I went to the Round Table ${ }^{6}$

They covered my eyes with a black tissue.

They put three boxes in front of me:

The first one contained gold, the second silver, and the third sand.

Me, King Kiamvu Panzu, I chose the sand, I chose the land.

Land is the thing that young and old revel in.

The historical claims that Kas Kasongo makes in this song are somewhat shaky: the original land-owners of what has become Kinshasa were a number of Humbu and Teke chiefs. They, and not the Yaka, were the ones who signed land treaties with Stanley upon his arrival in the Malebo Pool in the late 1870s and early 1880s. But the song does not aim to be a truthful historical account. As an anamnestic exercise in collecting, recollecting, recalling and transforming the

\footnotetext{
${ }^{2}$ In 2006, President Joseph Kabila launched his '5 Chantiers' or '5 Public Works' program, promising, amongst other things, a better urban infrastructure for Congo's cities. After the 2011 elections, the ' 5 Chantiers' program was rebaptized as 'Revolution of Modernity'.

${ }^{3}$ muYaka, singular of baYaka. The Yaka, a dominant ethnic group in the neighboring province of Bandundu, form a large part of Kinshasa's population today.

4 'Lunda': here this name is used in reference to Kasongo Lunda, the royal village of Mwene Putu Kasongo, the Yaka paramount chief who put up fierce resistance against the colonial intrusion into the Kwango area at the end of the nineteenth and the beginning of the twentieth centuries.

${ }^{5}$ Lion and leopard: totemic animals that symbolize traditional political power.

${ }^{6}$ The historical Round Table Conference took place in Brussels between January and May 1960 and brought together Congolese political representatives, traditional chiefs, and members of the Belgian political and economic establishment in order to negotiate the terms of Congo's independence. One of the thirty-nine traditional chiefs present at this conference was the Kiamvu, the Yaka paramount chief.
}

tracks of faded pasts, the song is meant to reveal something else, namely the fact that for many people in Kinshasa, and perhaps young people more than anyone else, the available frames of reference to claim an identity and a place for themselves inside the city not only come from the current world of neo-liberal globalization (and this in spite of the urban pimping that Kabila's 5 Chantiers set in motion) but are often rooted in much older local worlds. We are very much used to imagining the city as the hard core of modernity, although perhaps still unfinished at its fringes. In reality, however, the city as a whole also continues to be structured through the logic of a sort of pre-colonial and pre-urban notion of land 'commons'. Many of Kinshasa' inhabitants conquer and domesticate the city, navigate its spaces and infuse it with specific registers of power, value and wealth that have very little to do with the rationality of modern city planning. Instead they often find their origin in the logic of a sort of pre-urban notion of 'commons', a notion that strongly hinges on, and is deeply rooted in, a precolonial politics of land. It is this notion that structures the city in terms that continue to resonate more strongly than the more alienating official land use policy frameworks imposed by state and finance.

Here I want to take a closer look at what this autochthonous notion of 'commons' might still mean in the city today. The city is expanding at an alarming speed, and those who drive that expansion are no longer exclusively the villagers who migrate from the rural hinterland to the city. Although their influx continues to contribute significantly to the city's rapid expansion, processes of urban growth are also increasingly driven by internal migration within the city. People in the more central parts of the city have now started to move to the city's fringes, often in order to escape from all the social and ecological pressures that have become part and parcel of life in the overpopulated and promiscuous older parts of the city, mainly built under Belgian colonial rule after the Second World War.

The migratory movements from the countryside to the fringes of the city, or from the inner city to the periphery have given rise to a vast 'peri-urban' landscape (Beeckmans, 2015; Trefon, 2009b). In this emerging peri-urban fringe some parts are in higher demand than others, because they are accessibly located near a main road, for example, or less prone to soil erosion. This is the case for popular areas on Kinshasa's eastern fringe such as Kinkole, Bibwa and Mpasa, and here you might occasionally also encounter larger walled compounds containing more luxurious housing structures belonging to wealthier Kinois from within the city, such as politicians and high-ranking government officials, and increasingly also to Congolese from the diaspora. They share their new street and neighborhood with rural newcomers but also with a large, growing group of people who have been pushed out of the inner city because they can no longer afford the expenses of living there, or simply because they cannot find a space where to live.

To a large extent this process of urban expansion is made possible by land chiefs, the descendants of the original custodians of the land on which the city is built. These chiefs continue to play a crucial role in the 'opening up' of urban borders that is taking place on a vast scale at the city's rapidly expanding eastern, southern and western outskirts.

\section{Kinshasa's land chiefs and colonial rule}

Given the history of Kinshasa's land chiefs in the last hundred years, it is quite surprising that their presence has endured at all and that they have been able to continue to exert a strong, though not always officially registered or recognized, influence on the city and its possibilities for spatial expansion. Theirs has been a turbulent history, strongly marked by a colonial politics of repression, by various forms of expulsion, displacement, and forced relocation, as well as by unpredictable administrative reforms aimed at severing land chiefs' ties with their local power bases.

The more the land chiefs were engulfed and swallowed up by the city, the less visible and the more marginalized many of them became within the urban fabric. Nowadays, many of the villages and chiefly 
courts that once constituted the pre-colonial power landscape of the Pool's southern bank have simply vanished. But in spite of these erasures, the history of the original Humbu and Teke inhabitants of the Pool has never been fully obliterated. Spectres from the past still exist everywhere in Kinshasa, if only because many of the names of former chiefs, landowning lineages, clans and villages continue to live on in the city's memory and in the names of its municipalities and neighborhoods (cf. Toulier et al., 2010). Often the names no longer correspond with the original historical setting of these villages. This is mainly due to the impact of the colonial politics of urbanization that was responsible for forcibly evacuating and resettling many of the pre-colonial villages in the first half of the twentieth century. In this way, for example, several Teke villages along the banks of the Malebo Pool had to make way for expanding industrial and port infrastructures.

The disruptive processes of expulsion and relocation brutally severed chiefs' ties with the ancestral lands that constituted the source of their moral and political authority. It also had a profound impact upon the local power balances between chiefs and villages of the Pool during that period. From the earliest days of colonial presence, intrusive colonial land politics caused a great deal of tensions, even outright urban warfare, among the Humbu and Teke clans, who started to fight each other over territorial control of certain areas in the new and alien environment of the city.

The historical land treaty that Stanley signed with the powerful Teke chief Ngaliema in 1881 is a good example of this. Ngaliema came from the once powerful royal court of the Teke king, Makoko Iloo, on the opposite side of the river. ${ }^{7}$ Many years before Stanley's arrival in the Pool area, Ngaliema and other Teke emissaries connected to King Makoko's court had started to cross the river and settle along the Malebo Pool's south bank in order to secure Teke fishing rights on both sides of the river and to strengthen trading positions along the Pool as well as diplomatic and political relations with local Humbu chiefs who were already occupying the southern part of the river basin. Through intricate and still ongoing policies of Humbu-Teke matrimonial alliances, Ngaliema and other Teke chiefs were rapidly integrated into the political, social and economic system of the Pool's southern bank. ${ }^{8}$ In this way Ngaliema was incorporated into the court of Ngako, the Humbu chief of the important village of Kintambo (or Ntamo, as it was also called). But when Ngaliema took control of Kintambo after Ngako's death and signed a land treaty with Stanley in August 1881, this angered many of the autochthonous Humbu inhabitants. In their eyes, Ngaliema's authority was subordinate to that of the Kintambo lineage, which in turn owed allegiance to the area's most important Humbu authority, the Makoko (or chief) of Lemba, whose village was situated further inland and later gave its name to one of Léopoldville's main municipalities. These tensions escalated into a series of violent clashes between the Teke and the Humbu. At the end of 1891 or early 1892 and at the height of the Humbu-Teke conflict, the village of Kintambo was sacked and destroyed. A few years previously, in 1888, various Teke had already started to seek refuge on the Pool's northern banks, even though French military operations against noncompliant Kongo and Teke villages were in full swing there at the time as well. After the destruction of Kintambo, Ngaliema and many of his Teke followers also crossed the Pool to Brazzaville. And with the world as he knew it rapidly falling apart around him, Ngaliema himself died shortly afterwards in 1892.

Ten years after Ngaliema's death, Léopoldville had completely

\footnotetext{
${ }^{7}$ It was King Makoko Iloo (or Iloy) I who signed a first treaty on the third of October 1880 with Pierre Savorgnan de Brazza in Mbe, the location of Makoko's royal court at the time. The treaty allowed the French to set up a post at Nkuna, and it is this post that became Brazzaville in 1884 .

${ }^{8}$ Ngaliema himself married into the two important Humbu land-owning lineages of Lemba and Kimbangu. Each of these controlled a considerable part of the land on which Kinshasa would later be built.
}

swallowed whatever was left of Kintambo village. It disappeared as if it had never even existed, and today only the baobab in the garden of Bibi's Place, a local dancing club near the Kintambo Magasin roundabout, is a reminder of this troubled past.

And yet, the new city did not manage to completely erase the older political histories of its original inhabitants. Conflicts and fights between Humbu, Teke and other ethnic groups about the territorial control of the city and the Pool continued well into the twentieth century, and added yet another layer to the already considerable history of violence that the colonial presence had initiated. In fact, the colonial policy that was responsible for the removal of chiefs along the Pool's southern bank also created a local power vacuum that was perceived by other ethnic groups from upstream areas along the Congo waterway, as an opportunity to gain control over the old trading networks in the Pool. The Bobangi, for example, had been trading smoked fish, slaves, pottery and iron implements with the Teke of the Pool long before the arrival of Stanley, and the big men and chiefs of these two groups were related to one another through ritual ties of blood brotherhood and alliances. But until 1892, the Teke alone had set the trading rules in the Pool. For a while, they even managed to successfully bar the Bobangi from selling ivory to Europeans (cf. Vansina, 1973: 428). But after Ngaliema's death and the Teke's weakening territorial grip over the Pool due to colonial interference, clashes between Teke and Bobangi became increasingly frequent in Léopoldville, especially between 1920 and 1940.

The relocation and resettlement policy of the colonial ruler was responsible for the fact that many of Léopoldville's original landowning lineages gradually lost control over their land resources, even though they still consider this land to be rightfully theirs nowadays. However, they are rarely able to produce proper records of land ownership to substantiate these claims. This is hardly surprising seeing that the absence of land titles in itself results from a tradition of nuncupative negotiation embedded in a long and brutal history of colonial and postcolonial land reforms.

These reforms have also dramatically complicated the very notion of 'traditional' pre-colonial commons. Prior to the arrival of Stanley and his men, a land chief, who was often the head of the longest established lineage in a village, exercised authority over land allocation in a village and the villagers held usufruct rights to the land, which they used in frequently complex systems of shifting cultivation. These systems are still very much in place in large parts of the country, but colonial rule in the Congo Free State (1885-1908) and the Belgian Congo (1908-1960) profoundly altered the legal principles that organized and underpinned access and entitlement to land before the arrival of the colonizers. During the colonial era, new land law systems were established to favor the exploitation of the country's natural resources by the new rulers and redefined large parts of the country as 'vacant and ownerless land'(terres vacantes et sans maître), a label that was never clearly defined and often ignored the hunting and gathering rights of local groups of inhabitants. Moreover, lineage lands that local villagers purposefully allowed to lie fallow for future farming were often considered to be 'vacant' by the colonial system. This allowed the colonial authorities to annex this land, thereby radically emasculating the political authority of land-owning lineages across Belgian Congo, while creating the possibility of relocating and shifting entire populations around.

\section{Postcolonial land reforms}

In addition to these profound colonial changes, the controversial post-colonial Bakajika land reform of 1966 further complicated land matters. In June 1966, the Congolese government promulgated the Bakajika Law, which was aimed at undoing colonial concessions granted before independence. The new land law was heavily promoted at the time by the emerging Mobutist regime's propaganda machinery as an attempt to break the former colonizer's continuing hold over land, but in reality it did nothing to return land ownership to local 
autochthonous groups, who continued to regard this land as part of their ancestral heritage. On the contrary, the Bakajika Law was the first in a series of post-colonial laws designed to ensure stronger government control over land and mineral resources. The new land law system effectively continued the colonial system of land control, which enabled state ownership of all wealth 'above and below' the ground, thereby ensuring that public mineral (and oil) rights went to the government. As a result of the new legal framework, customary law as codified under colonial rule formally ceased to be a legitimate source of land rights (Kisangani and Scott Bobb, 2010: 36-37). In the end, the Bakajika legislation further alienated local populations from their lands and paved the way for a great deal of legal uncertainty. ${ }^{9}$ What continues to complicate matters greatly even today is the fact that privately owned land is rarely properly registered. Tenure, therefore, remains a very precarious thing in Congo. This fact makes it difficult to use land as collateral for a loan, for example, and it has discouraged farmers from investing capital on essential land improvements needed to increase agricultural production. As noted by Meditz and Merrill (1994: 171), the land situation in the 1980s and 1990s was exacerbated by the limited government resources available to embark on a large-scale land registration as well as the common practice among concession holders of bribing local officials to postpone indefinitely investigations of further development activities on the concession.

This observation remains as true today as it was in the early 1990s. Political interference has also exacerbated land disputes and obstructed their resolution, while the theft or disappearance of documents and files relating to land disputes by corrupt government officials, judges, army officers, businessmen and family members of land chiefs is another common practice that has added to the number of unresolved land disputes. This is clearly illustrated in recent evictions and land conflicts in the Kingabwa marshlands, an area under pressure because of the expected opportunities that the construction of a new satellite city, known as La Cité du Fleuve, promises to bring (see De Boeck, 2011).

\section{Matrilineal principles under pressure}

The state is not alone in complicating land matters. Land chiefs themselves often challenge each other's authority, and the fact that the boundaries of their lands have never been clearly demarcated further intensifies conflicts between different land-holding lineages. However, what most debilitates the notion of 'traditional commons' is the frequent infighting amongst relatives within many of the still existing Humbu and Teke chiefly lineages. The title of land chief is normally passed down along matrilineal lines, usually from mother's brother to sister's son, although in Humbu landowning lineages, it is not uncommon for a doona, that is, a sister of a deceased land chief, to inherit the title temporarily if no suitable candidates are available among the chief's sister's children. However, in the city today, these principles of matrilineal inheritance have come under increasing pressure. More often than not, such rules are contested by the chiefs' own children, who believe that they, rather than their matrilineal cross cousins, should have a right to the title of land chief. We witness here a major switch from a matrilineal to a more patrilineal system of de facto inheritance in which elders are constantly overruled by their own offspring. The latter frequently start to sell land on their own account, even if they do not have the right to do so according to standard Humbu/Teke hereditary kin-based mechanisms of land control and

\footnotetext{
${ }^{9}$ On 31 December 1971, a constitutional amendment and the promulgation of a new land law empowered the state to repossess all land rights. In July 1973, the General Property Law was enacted to organize the country's new legal framework concerning land issues. With the enactment of the 1971 and 1973 laws, all lands now belonged to the state, and individual land rights had to derive from either state concessions or indigenous customary law (Meditz and Merrill, 1994: 171).
}

'ownership' rights. What this boils down to in practice is that the same plot of land might be 'sold' several times by different individuals from one land lineage to several different buyers. Local police officers and administrative agents who have to register the land sales are often part of the game, as it offers a chance to increase their meagre wages. It is not hard to imagine to what extent this evolution forms the basis of lasting land disputes and adds to the already existing general confusion and legal insecurity surrounding land and property ownership.

Let me illustrate this with the case of Samuel Mandefu Bie who was, until his death in 2016, chief of the old Teke-Humbu landowning lineage of Kimbangu village, together with Kintambo and Kinshasa one of the most important pre-colonial villages. Although the village itself has been completely eaten up by the city, chief Mandefu still lived in the same compound where the first colonizers encountered his predecessor at the end of the nineteenth century. It is located slightly to the east of Kingabwa, in what is currently known as the Petro-Congo neighborhood of the municipality of Masina. The chiefly court is easy to find because of a giant baobab tree, which grows in the centre of the compound and is said to have been planted by Stanley's men (Fumunzanza Muketa, 2008: 224). At the back of the compound is a small cemetery where former chiefs lie buried.

One of these former chiefs was Paul Imbali (see also de Saint Moulin, 2012: 58ff). During Paul Imbali's reign, the colonial state requisitioned a large portion of his lineage's land. It was on this land that the international airport of Ndjili was built in 1953. However, even after the construction of the airport, Imbali continued to sell parts of the same land to various other parties. As a result, he was sentenced to several years in jail, which he spent in various prisons throughout the country. During his absence, the colonial administration replaced him with a certain Louis Mbimi. But when Imbali eventually returned home shortly after independence, he took up his chiefly position again until his death in the mid-1980s. After his death, the title of chief was supposed to pass on to his sister, a certain Mama Mambwala, but the latter refused to take on this responsibility and handed the title to another member of the family instead. This new chief was called Jacques Kwe, but he drowned in the Congo River only a short time after his investiture. Thereupon, Mama Mambwala, in her position as power broker, decided to give the title to Daniel Ngangwele, one of Imbali's four official children, even though Imbali was not Daniel's biological father (after being widowed, Daniel's mother remarried with Imbali and moved into his polygamous household with her son).

The fact that Daniel Ngangwele was chief Imbali's adoptive son was not, however, the primary reason that Imbali's other children (two sons and a daughter, Bibiane Ngamayele) disputed Mama Mambwala's choice. The real reason might have been that, towards the end of his life, Imbali himself disinherited his adoptive son. He apparently took this decision when it was discovered that Daniel was having an affair with one of his father's wives. Whatever the truth of the matter, Daniel's enthronement was the start of a struggle between Daniel and his two brothers, who both died in the 1990s, as well as with his sister, Bibiane. When Daniel Ngangwele himself died in 2009, Mama Mambwala, a very old woman by then, managed to outmaneuver Bibiane, who considered that the title should finally become hers, by handing it instead to Samuel Mandefu, one of Paul Imbali's sisters' sons. Samuel Mandefu had been Daniel Ngangwele's chauffeur for years and had been very close to his uncle. His enthronement therefore made a lot of sense in the eyes of many, because it also meant a return to the standard matrilineal succession procedure that had been upset by Daniel Ngangwele's own succession to the title. But while Mandefu's enthronement conformed to recognised rules of succession and was formally endorsed by the urban authorities in 2010, it did not succeed in ending the family conflict. On the contrary, both Bibiane Ngamayele and one of Daniel Ngangwele's own sons, Tati Imbali Mukoo, refused to recognize Mandefu as the legal heir to the title, and claimed the title as rightfully theirs instead. Early 2010, Tati even set up his own parallel court in his father's compound, near the old baobab tree. Tati and several of his siblings also consigned 
the old and frail chief Mandefu, who until then had been living in the compound's main house, to a small shack at the back of the family plot. In fact, between 2012 and 2015, I visited the compound several times and each time Tati and his siblings made it impossible for me to speak to Mandefu. It was only during my last visit in March 2015 that I finally managed to speak to the old man himself while Tati was in jail because of a land dispute with both Mandefu and Bibiane. At that point, Mandefu was in very bad physical shape for he too had spent several months in prison due to the same land affair Tati and Bibiane were involved in. In fact, independently from each other, Bibiane and Tati had started to sell plots of agricultural marshland that they considered part of Daniel Ngangwele's 'heritage' but that had already been sold by Mandefu in the meantime. These sales led to an internal family conflict that came to a head on 2 September 2010 when Tati was abducted in broad daylight at a bus stop in the Masina Petro Congo neighborhood by uniformed men. In the evening of the same day, the same uniformed men forced themselves into Samuel Mandefu's house and kidnapped him as well. Both men were taken to an undisclosed place, where they were tortured and robbed of their personal belongings before being released twenty-four hours later. Tati subsequently took the matter to court. There it was found that the uniformed men, who claimed to be members of a non-existent Joseph Kabila Special Intelligence Service (Division spécial de renseignements de Joseph Kabila-DSRJK) and to have acted on direct orders of the president himself, had actually been hired by Bibiane. In spite of this revelation, Bibiane won the court case and was acquitted. In the following years Tati and Bibiane continued to contest each other in court, which finally lead to the temporary arrest and imprisonment of both Tati and Mandefu in 2014.

It is clear that Bibiane could not have pulled this off without some serious backing from a number of other, more important actors. These included high ranking army officers and members of the public administration who were powerful enough to successfully bribe court judges. All of them were using Bibiane's (unrightful) claim to the status of chiefly heir to cash in on her illegal land sales. While Bibiane skilfully manipulated these contacts and networks to triumph over family members, it also catapulted her into a different and more dangerous power game with mightier opponents.

The following section will use the case of Bibiane and her family to illustrate to what extent chiefly families continue to play a crucial but also very complex and ambivalent role in urban land issues and to show how the land claims made by (often internally weakened) chiefly lineages become part of a much broader competition over land that characterises the ways in which politics of space is played out on a large scale in Kinshasa more generally.

\section{Competing claims on urban space. The complexity of land issues in Kinshasa's marshes}

The enforced removal of several Teke villages from the river banks of the Malebo Pool in the first half of the twentieth century freed up a great deal of space. Most of it was rapidly filled in by industrial and port infrastructures, but many of the more marshy areas along the river bank remained unused until Emmanuel Capelle, the head of the colonial administration for the indigenous cités of Léopoldville between 1945 and 1952, suggested that a green belt, a ceinture agricole (Capelle, 1947: 52 ), should be created around the city to promote peasant horticulture there. This, Capelle strongly felt, was needed to feed the rapidly expanding city, while it would also keep part of Léopoldville's booming population busy and check their idleness. To this end, from 1954 onwards, plots in the marshy area where the Ndjili River enters the Pool were allotted mainly to unemployed women who had recently migrated from the rural hinterlands to the city, and kitchen gardens were set up in an attempt to put these women to work.

After independence, the colonial project of peasant horticulture was resuscitated and expanded (Mianda, 1996:93). Promoted by the Department of Agriculture and Rural Development and with the support and co-operation of the French, the scope of the initial colonial project was considerably extended during Mobutu's reign (1965-1997). At the end of this period, horticulture in the Pool encompassed most of the marshlands between Kingabwa and Ndjili airport, and vegetable production in this area started to play an important role in Kinshasa's economy, providing fresh vegetables to markets throughout the city.

Ever since, the Malebo Pool's south side has steadily transformed into a vast agricultural zone. In the 1980s, a South Korean agricultural company started to develop rice paddies in the Malebo Pool near Kingabwa, but this project was abandoned after widespread waves of looting hit Kinshasa in 1991 and 1993. The local population quickly moved in to occupy the rice paddies, and it did not take long before they started to expand them, often filling and empoldering the Pool's marshes with very basic tools such as shovels, and even their own bare hands.

In this fashion, the inhabitants of the neighborhoods along the Congo River, have continued to convert large parts on the DRC side of the Pool into arable land. By now, in certain areas, the empoldered area is already reaching several kilometers into the Malebo Pool.

As Mianda reports, even after the introduction of the Bakajika land law that abolished customary kinship rules determining access to land, these rules continued to co-exist with the new state law. 'As a result', she states, 'those who wish to undertake garden production in Kinshasa must first negotiate with the chiefs and then acquire the title to the land from the civil authorities' (Mianda, 1996: 93). This remains the case even today in that access to a piece of horticultural marshland often needs to be negotiated with local chiefs, although it is the urban, provincial and national administration that has the right, in theory, to allocate the land to farmers, and although the farmers themselves contest both the chiefs' and the state's authority over these polders. According to the farmers, this is land that did not previously exist but that was created by means of their own efforts, which therefore gives them every right to occupy it and consider it theirs.

However, their claim is contested not only by land chiefs but also by the urban authorities. From the National - and since the administrative decentralization reform (see Trefon, 2009a) increasingly from the Provincial - Ministry of Agriculture to Kinshaa's Governor and all the way down to the municipality level, these various administrative organs have been making attempts to impose a legal framework in order to direct, control and, above all, tax these new farming activities on often previously non-existent land. Each farmer is supposed to make a payment to the land registry office of the province of Kinshasa. This is the prerequisite in order to obtain a contrat d'exploitation ('operating contract') from the Urban Division for Rural Development, and a permis d'exploitation agricole ('agricultural operating license') from the Inspection of Rural Development and Agriculture, a unit on the municipal level. Only after meeting all these administrative measures can someone officially acquire the usufruct rights to a small horticultural plot for as long as they want on condition that they can prove it is continuously cultivated. In theory, the municipality is supposed to send an inspector to check on this once a year. In practice, however, none of these regulations and procedures is applied in any straightforward manner. The inspector rarely comes, and since none of this land is shown in detail on any official map, the authorities in many cases have no knowledge of which surface area of land should be taxed.

In fact, the Pool's huge garden belt is organized outside any clearly defined form of government control on the ground. The actual 'ownership' of these gardens is in the hands of some eighty farmers' associations that represent more than a thousand farmers, most of whom are women. These associations have divided the riverine farmlands into fourteen secteurs which, in turn, are sub-divided into a varying number of blocs or 'squares', each consisting of hundreds of tiny garden plots that rarely exceed six acres. A président de secteur, who officially represents the level of the municipality but in reality acts totally independently, is aided by a number of chefs de bloc and oversees the farming activities in each sector. He also organizes and oversees the 
contacts with the thousands of women who each day buy up the gardens' produce and ensure that vegetables are distributed throughout a large part of the city's numerous markets.

Farmers within each 'square' and sector all know each other well, hold regular meetings and regularly collaborate with one another, but these structures of cooperation and solidarity can also easily unravel. Garden plots are in high demand and holding on to one is a relentless struggle. Maintaining a claim to a garden plot requires constant physical presence and occupation. If, due to illness or some other reason, a farmer fails to show up for a couple of days, her co-farmers will not hesitate to rent it out to another person who will immediately take over her place and hold on to it for as long as possible. As elsewhere in Kinshasa, one can never be sure of 'ownership' of a strategic spot or place. The extreme atomization and morcellation of space in the city makes it impossible for someone to claim a spot as exclusively their own, and ownership is always disputed because of the constant need to negotiate one's presence with a multitude of others who make similar claims. If presence is an absolute must to stake out a claim, it is also determinedly contested. This in turn regularly results in disputes and conflicts.

Skirmishes, confrontations and contestations of this kind not only take place on this 'micro-scale' (Ansoms et al., 2014) but also spread out to other levels. Again, the riverine fields provide a good example. Since agricultural land is in high demand in Kinshasa (cf. Wagemakers and Makangu Diki, 2011; Wagemakers et al., 2011), the creation of new arable land in the Malebo Pool has led to innumerable and sometimes violent clashes in which the parties involved contest one another's ownership and right over previously non-existent land.

These conflicts are mainly played out first between the farmers' associations and the Teke and Humbu land chiefs, such as the family of chief Mandefu, as was mentioned before. Let us return briefly to the case of Mandefu, Tati and Bibiane.

Mandefu and his family basically ran out of land to sell along the riverbanks of the densely populated municipality of Masina. As previously explained, a large part of the communal lands in the care of this lineage was confiscated by the colonial state in order to build the airport of Ndjili, and whatever land remained afterwards has long since been parcelled out. That is the reason why Mandefu, Bibiane and Tati turned to these newly available plots of horticultural land, claiming ownership rights over what they themselves consider to be 'ancestral' land (even if that land was non-existent twenty years ago). All three of them started to sell large stretches of these horticultural marshlands without the farmers' consent, even though the farmer associations of this sector had previously negotiated access to and 'ownership' of this land with chief Paul Imbali, the father of Bibiane and grandfather of Tati. All of this lead to a multi-sited conflict in which the farmers opposed not only Mandefu, Bibiane and Tati, who were already fighting amongst themselves, but also the various new 'owners' of these illegally sold plots. The new 'owners' also started fighting one another, as the same plot had sometimes been sold simultaneously to two or more people. All these conflicts, however, did not discourage newcomers from moving into the area in their hundreds. The farmers' marshlands were thus transformed extremely rapidly into a shanty area, and in the process a large portion of the farmers' plots was destroyed. By 2010, a considerable number of shacks had emerged in what is essentially a very unhealthy swamp that is totally unfit for habitation as it lacks even the most basic infrastructure in terms of water, electricity and sanitation, and is regularly flooded.

What complicated matters even more is that the farmers, the competing 'chiefs' (Mandefu, Tati and Bibiane) and the owners of the newly-constructed houses were each backed by various administrative and judicial actors on the municipal and the provincial level. This created a highly explosive situation leading to violent clashes among the various parties involved. In late 2009 , for example, the farmers turned for support to the Provincial Minister of Agriculture and Rural Development, Mr. Noel Botakile. He promised to help the farmers, even though in the meantime some of the exact same land in their sector had been leased out by the office of the Governor of Kinshasa to a Chinese agricultural development project. However, in response to the farmers' appeal to the Ministry, Bibiane successfully mobilized her military associates. As a result, a number of soldiers were posted in and around the expanding shanty area to protect shack owners from the attacks of furious farmers reclaiming 'their' fields. The conflict further escalated in early 2010 when these soldiers opened fire at policemen who were accompanying the provincial Minister Botakile during his visit to the disputed site. The minister subsequently ordered the shacks to be destroyed. Bibiane retaliated by taking the farmers' association, the Chinese development project and the Ministry to court in order to secure her interests, as well as those of the army officers who were backing her behind the scenes. The first court hearing took place in November 2010 at the Tribunal de Grande Instance of Ndjili, in the presence of Minister Botakile himself. Also present were Pierre Bukasa (the president of the Union Nationale des agriculteurs, éleveurs et pêcheurs $d u$ Congo) and two representatives of the city's public administration. It seems that Bibiane's lawyers successfully bribed the court instances because further hearings were postponed and to my knowledge the court has never reached a firm conclusion since then. To this day, Bibiane has not been ordered to return the illegally sold land to the farmers.

The complexity of this specific case, with its multitude of opposing actors and stakeholders on various interconnected formal and informal levels, is by no means unique in Kinshasa. Many other land conflicts have been unfolding with a similar intensity and have pitched local politicians, farming associations, civil servants, land chiefs and private investors against one another in constantly changing constellations.

\section{Urban expansion and the opening up of land in the city's rural periphery}

But even if land conflicts of this nature are common all over Kinshasa, their level of intensity can vary greatly. Along the banks of the Pool, where access to new land is limited and where the chiefs' control over land has become weakened, the arrival of the Cité du Fleuve satellite city project and of a number of other residential or industrial developments have undeniably raised the stakes and intensified the level of conflict. This is the case to a far lesser extent in more peripheral parts of the city, where land chiefs, such as several Teke and Humbu chiefs in the city's eastern and western periphery, have managed to hold on to their lands a great deal more firmly.

Some of the chiefs in these areas have been assimilated into the fabric of the urban and provincial administration as chefs de groupement, which means that they have official, albeit limited, administrative authority over land matters in their administrative groupement unit. However, under the umbrella of the official administrative architecture, there remains a much broader hierarchical political network stretching across the whole of Kinshasa province and far beyond and with roots in a pre-colonial territorial politics defined by kinship and alliance. Whatever their legal status or official administrative function, all these other chiefs and sub-chiefs within that wider web continue to exert their influence over land matters as well. Some of them are recognized by the state as chefs coutumier, a title that excludes them from any immediate administrative authority (as in the case of Mandefu, for example). However, many others are simply not recognized by the state at all, even though they too continue to play an active role with regard to land matters.

Chiefs still control large tracts of land particularly in the more rural parts of Kinshasa province to the south-west of the city in the urban districts of Lukunga, Funa and Mont Hamba, and to the east in the urban district of Tshangu as well as on the Bateke Plateau. It is no coincidence that these are also the areas of expansion for the city itself nowadays. In this process of rapid urban growth, these land chiefs play a far more decisive role than what may seem justified by their low or 
non-existent administrative status seeing that it is simply impossible for an individual, a real estate company or an industrial investor to obtain a piece of land without preliminary negotiations with them.

After negotiating with a chief over of a piece of land and making a first payment, which is defined in terms of a 'gift', the buyer receives a document, which is often a mere handwritten note signed by the chief or one of his representatives. ${ }^{10}$ This note, which acknowledges the buyer's intent to settle on the land, is needed when the buyer presents him- or herself at the local police station and the office of the chef de quartier. Once the chief's letter is made official by their stamping the document in question, the buyer can then start to legalise the property by going through all the different administrative levels and procedures, which reach from the municipal level all the way up to the Land Registry at the Central City Hall. This is a process that may take many years to complete and requires substantial sums of money to be paid at each level of the administrative hierarchy. Meanwhile back on the piece of land obtained from the local land chief, the buyer has to prove the genuine intention to occupy it. The best way to do so is to start fencing the plot and building something on it. This needs to be done within three years after acquisition of the plot, ${ }^{11}$ or else the land will automatically return to the chief and give him the right to sell it again to another party. Many chiefs, however, do not bother to wait that long and they resell the land before the end of this period, or else they sell the same plot to different buyers at the same time. In other cases, the chief's own children might sell the same plot to someone else without their father's knowledge or consent. All these instances trigger conflicts, litigations and legal suits that people can never be certain to win.

More importantly, however, chiefs will never interpret a land sale as being something final. It never severs their deep historical ties to that land. In their mind, therefore, they do not sell the land itself, but merely the usufruct right to that land. No matter what state law might have to say about this, as far as these chiefs are concerned the land is inalienable ancestral heritage and will therefore always remain theirs.

What 'selling' the land often means to them is not so much that it brings in money but that it represents a specific moment that sets in motion the possibility of exchange; it offers chiefs an opportunity to extend their own networks and reshape the city into an arena that allows them to generate 'tributary' dependencies with the person who 'receives' land and with the state who has to formalize the land sale. Rather than selling land, chiefs 'give' land. In this way, a land settlement is converted into a never-ending deal that will have to be renegotiated time and again by the occupant of the plot, and will have to be reconfirmed through the 'circulation of gifts' that strengthen the relational ties between the patron (the chief) and his client. Chiefs thereby infuse the space of the city with their own political economy and morality of gift exchange. This allows them to personalize the city's institutional level, and re-institutionalize the personal sphere into alternative networks and spaces of palaver, exchange and complicity that enable a circulation of commodities, money and people in ways with which these chiefs are more familiar and know better how to master and control. In this way, chiefs do not only recast their relationship with the new occupant of 'their' land, they also manage, in various degrees and with varying success, to redefine their relationship with the city and the state in terms of their own more personalized 'feudal' structures of deliberation, sharing of power and distribution of wealth. That, in the end, is the real value of land for these chiefs: it allows them to redefine a mere patron-client relationship with the state, in which they occupy the subordinate position, and turn it into a more

\footnotetext{
${ }^{10}$ In some cases chiefs continue to use copies of title deeds used by the colonial administration.

${ }^{11}$ This does not immediately have to be a house construction, for that involves financial resources that few people have at their disposal. Instead, the construction of a single wall, or even a pit latrine already suffices to demonstrate that people seriously intend to occupy this plot.
}

empowering political economy of exchange in which these political and economic relations with the state can be shifted and turned around. A good illustration of this is the fact that even people at the highest levels of state power, including the president and the city's governor, are forced to take the existence of these chiefs into account if they want to acquire land. This fact was brought home to me in March 2012 when I accompanied a friend of mine to Bibwa, an old village located on Kinshasa's eastern outskirts, to negotiate the acquisition of a small plot of land under the care of the local Teke land chief of Bibwa, chief Munziami Lita, an old man who was also renowned for his skills as a bonesetter.

We were guided to a small house where chief Munziami was treating his patients. When he finally finished, he invited us to his own compound, easily distinguishable because of an old baobab tree that overshadowed the chief's main house. At the back of the house, there was also a small cemetery that held the remains of some of Munziami's predecessors and other relatives. After offering the chief a standard opening gift, consisting of some kola nuts and salt, a piece of cloth and a bottle of whisky, my friend started to negotiate the conditions of the sale, and before long he had reached an agreement with old Munziami. Afterwards, we walked to the allotment in the company of one of Munziami's grandsons, who mentioned how lucky my friend was to have been given this plot of land, because his new neighbor would now be Mama Olive, President Kabila's wife and Congo's First Lady. Apparently, she too had recently come to Munziami's courtyard with gifts to obtain land with a view to constructing a gated apartment community in this much coveted part of the city. After a brief negotiation, Munziami 'gave' her twelve plots adjacent to that of my friend. The fact that in order to access land, even Kabila's wife felt obliged to sit down with chief Munziami, who is not even a chef de groupement and therefore has no immediate official function in the city's administration, is quite telling and indicates the chiefs' continuing hold over land; a hold that allows them to infuse the space of the state with their own political and moral economy of exchange, an economy still so powerful that it succeeds to force the state to adapt to its terms and even manages to convert the president's wife into a client.

\section{Conclusion}

In the end, what this also means is that the post-colonial city is only capable of growing and expanding thanks to actors whose frame of reference is not that of the state, nor of colonialist modernity or postcolonial neo-liberal agendas. Instead, it is rooted in the kinds of rural and pre-colonial worlds that the colonizer tried so hard to eradicate and the city itself has wanted to expel from its surface for a long time now. Paradoxically, an important way forward for the city to exist in the future seems to reside in a past that, upon closer inspection, has never stopped to invade and re-territorialize the space of the urban.

It it is this paradox that ultimately constitutes this city. More than ever, and against all odds, land chiefs continue to emerge as crucial figures in the making of the contemporary city. Holding the key to land they do not legally own but nevertheless consider theirs, they are the ones who open up a city yet to come. And it is in this capacity of land guardians that chiefs act as crucial safety and relief valves by means of which the city is capable of reducing the demographic pressures that would otherwise cause it to explode and make it totally unlivable.

At the same time, their position also remains fundamentally ambiguous and double-edged. Within the urban context, the figure of the chief is both respected and strongly contested. There is no denying the fact that the chiefs' continued involvement in land matters operates as a very efficacious form of urban sabotage that deeply disturbs, perverts and deregulates the city's functioning on the institutional level as well as in daily life. Triggering a lot of legal uncertainty and conflict, their presence engenders a range of shady deals and an endless carrousel of trade-offs and arrangements that make a more rational management of the city virtually impossible, thereby turning life in the city into a 
constant struggle. Of course, chiefs themselves are never in full control of the game either, and their power is also often reduced and weakened by the city. But on certain levels, the specific moral and political economy they inject into the city is powerful enough to force the state and the formal official political domain to adapt to its logic. Concomitantly, it also provides more inclusive openings for a large part of Kinshasa's inhabitants who feel abandoned by the state and excluded from the city. The social, moral, political and economic frameworks that these chiefs embody still resonate strongly with many of these urban dwellers, and as Kas Kasongo's song in the beginning of this contribution illustrated, they also continue to offer anchorage points of (ethnic) identification and belonging in a city that does not otherwise offer them a place.

\section{References}

Ansoms, An, Wagemakers, Inge, Walker, Michael Madison, Murison, Jude, 2014. Land contestations at the micro scale. Struggles for spaces in the African marshes. World Dev. 54, 243-252.

Beeckmans, Luce, 2015. Kinshasa : a City of 'Squatters' and planning schemes. In: Bogaert, Jan, Halleux, Jean-Marie (Eds.), Territoires périurbains : développement, enjeux et perspectives dans les pays du Sud. Presses Agronomiques de Gembloux, Louvain-la-Neuve, pp. 249-258.

Capelle, Emmanuel, 1947. La cité indigène de Léopoldville. Centre d'études sociales africaines/Centre d'études des problèmes sociaux indigènes, Léopoldville / Elisabethville.

De Boeck, 2011. Inhabiting ocular ground: Kinshasa's future in the light of Congo's spectral urban politics. Cult. Anthropol. 26 (2), 263-286.

De Boeck, F., Baloji, S., 2016. Suturing the City. Living Together in Congo's Urban Worlds. Autograph ABP, London.

de Saint Moulin, Léon, 2012. Kinshasa. Enracinements historiques et horizons culturels. L'Harmattan/Royal Museum of Central Africa, Paris, Tervuren.

Fumunzanza Muketa, Jacques, 2008. Kinshasa: d'un quartier à l'autre. L'Harmattan,
Paris.

Kisangani, Emizet François, Scott Bobb, F., 2010. Historical Dictionary of the Democratic Republic of the Congo. Scarecrow Press, Lanham, MD.

Lund, Christian, 2008. Local Politics and the Dynamics of Property in Africa. Cambridge University Press, Cambridge.

Meditz, Sandra W., Merrill, Tim (Eds.), 1994. Zaire. A Country Study. American University., Washington, DC.

Mianda, Gertrude, 1996. Women and Garden produce of Kinshasa: the difficult quest for autonomy. In: Ghorayshi, Parvin, Béranger, Claire (Eds.), Women, Work and Gender Relations in Developing Countries: A Global Perspective. Greenwood Press, Westport, CT / London, pp. 91-101.

Robinson, Jennifer, 2013. The urban now: theorising cities beyond the new. Eur. J. Cult. Stud. 16 (6), 659-677.

Shipton, Parker, 2009. Mortgaging the Ancestors. Ideologies of Attachment in Africa. Yale University Press, New Haven / London.

Simone, Abdoumaliq, 2004. For the City Yet to Come. Changing African Life in Four Cities. Duke University Press, Durham.

Toulier, Bernard, Lagae, Johan, Gemoets, Marc (Eds.), 2010. Kinshasa. Architecture et paysage urbains. Somogy Éditions d'Art., Paris.

Trefon, Theodore (Ed.), 2009. Réforme au Congo : Attentes et désillusions. L'Harmattan / Royal Museum of Central Africa, Paris / Tervuren [Series 'Cahiers Africains', $n^{\circ}$ 76].

Trefon, Theodore, 2009b. Hinges and fringes: conceptualizing the peri-urban in Central Africa. In: Locatelli, Francesca, Nugent, Paul (Eds.), African Cities. Competing Claims on Urban Spaces. Brill, Leyden / Boston, pp. 15-35.

UN Habitat, 2010. The State of African Cities 2010. Governance, Inequalities and Urban Landmarkets. Nairobi: UNEP Regional Office for Africa and the Arab States of the World's Cities 2010/2011.

Vansina, Jan, 1973. The Tio Kingdom of the Middle Congo, 1880-1892. Oxford University Press, Oxford.

Wagemakers, Inge, Makangu Diki, O., 2011. Governance of Urban agricultural space: struggle for Land in Kinshasa (DRC). In: An, Ansoms, Maryse, Stefaan (Eds.), Natural Resources and Local Livelihoods in the Great Lakes Region of Africa. Palgrave MacMillan, Basingstoke, pp. 68-82.

Wagemakers, Inge, Makangu Diki, O., De Herdt, Tom, Kitshiaba, J.-M., 2011. Lutte foncière dans la ville : gouvernance de la terre agricole urbaine à Kinshasa et à Kikwit. In: De Herdt, Tom (Ed.), A la recherche de l'Etat en R-DCongo : acteurs et enjeux d'une reconstruction post-conflit. L'Harmattan, Paris, pp. 73-114. 